\title{
Erratum to: Induction and decay of short-term heat acclimation
}

\author{
Andrew T. Garrett $\cdot$ Niels G. Goosens • \\ Nancy J. Rehrer · Mark J. Patterson • \\ James D. Cotter
}

Published online: 14 October 2009

(C) Springer-Verlag 2009

Erratum to: Eur J Appl Physiol

DOI 10.1007/s00421-009-1182-7

Unfortunately, there is an error in the third author's name in the author group.

His middle initial is $\mathbf{J}$. and not G. This is corrected here.

The online version of the original article can be found under doi:10.1007/s00421-009-1182-7.

A. T. Garrett · N. G. Goosens - N. J. Rehrer · J. D. Cotter School of Physical Education, University of Otago,

Dunedin, New Zealand

\section{J. Patterson}

Defence Science Technology Organisation (DSTO),

Melbourne, VIC, Australia

\section{Present Address:}

A. T. Garrett ( $\square)$

Division of Sport, Health and Exercise, School of Life Science,

University of Hertfordshire, College Lane, Hatfield,

Hertfordshire AL10 9AB, UK

e-mail: a.t.garrett@herts.ac.uk 